\title{
The Role of Technology in Biology Teaching During and Post Pandemic Era: Challenges and Opportunities
}

\author{
Rizqa Devi Anazifa* \\ Biology Education Department, Universitas Negeri Yogyakarta, Indonesia \\ *Corresponding author. Email: rizqa1992@uny.ac.id
}

\begin{abstract}
The COVID-19 pandemic forces teachers and students to adapt rapidly to the online learning situation. Teachers have to adjust the traditional face-to-face instruction to online learning. This change affects science learning, especially in teaching biology. This study aims to explore the roles of technology in teaching during and post Covid-19 pandemic in biology courses. We conducted qualitative study by interviewing six senior high school biology teachers from public and private school in order to collect the information. We also analysed Learning Management Systems (LMS) and videos to gather the information about teaching strategies implemented during online leaning. The result explains that teachers have been implementing synchronous learning by using various video conference platforms and asynchronous learning using various types of LMS. Teachers also use various learning media, especially to help them conducting laboratory work. During online learning, teachers also experience many obstacles in technical issues and reduced interaction during learning process. However, this online learning will be continued in the future with various forms, which combine online learning and face-to-face learning- such as blended learning or flipped learning.
\end{abstract}

Keywords: Biology Teaching, Learning Strategy, Technology

\section{INTRODUCTION}

The coronavirus (COVID-19) pandemic forces the educational system to change. Schools, teachers, and students have to adapt to the online learning situations. Teachers, especially, have to move from the traditional face-to-face classroom to the virtual classroom. This change affects the science learning, especially biology courses. The effect of a pandemic on biology learning is that, prior to the pandemic, learning that was carried out directly to introduce real biological objects could not be carried out due to social distancing. That real object must be replaced with learning media, such as photos, videos, animations, or others form of learning media. Lock-down in several educational facilities also makes laboratory activities unable to be carried out.

Ideally, biology learning should be conducted by introducing the real objects directly to students, so students have hands-on learning experience. This learning process encourages students to observe and explore the scientific phenomenon and possibly carry out the experiments. Unfortunately, in distance learning formats these objects cannot be presented directly in the classroom. They must be replaced by technology such as virtual laboratories, augmented reality, virtual reality, or other biology learning media. Those media presented in the classroom aims to provide the closest experience to the real object.

There are several alterations in teaching strategy during pandemic. Teachers leverage the online delivery mode, such as interactive discussion, student-led teaching, the application of game-based learning to increase students' motivation and attention [1]. In addition, the implementation of learning must also provide meaningful and authentic that involves the application of new skills and knowledge such as teambased project that encourage students to work collaboratively and solve problem creatively with the support of social media tools [2]. Changes do not only occur in learning strategies but also in assessment. For 
example, the teacher needs to change the completion of the task to be more flexible [3].

Learning during pandemic has been shifted into distance learning, so that teachers were urged to use technology in order to teach students. There are ten best practices for taking experiential learning online, 1) provide clear structure and objectives for virtual program, 2) provide zoom and virtual etiquette, 3) find out students' needs, 4) create a monitoring network for students, 5) use synchronous tutorials, 6) facilitate networking and community building by social event, 7) leverage online resources, 8) using workshop to supplement training experience, 9) organize for one-toone meeting, 10) leverage virtual conference [4].

Learning using technology can enhance learning. When computer technology used with the appropriate pedagogical strategies can be used to assist learners in understanding biological concepts and processes [5]. Using computer in teaching also gives greater access to information [6]. It also promotes students critical thinking and problems solving. Moreover, it gives them meaning to learning. Hence, integrating computer technology in learning biology can enhance students' achievement.

In term of using technology in the biology classroom, teachers can display visualization and a projection screen to explain and illustrate the biology concept and also using simulation to explore phenomenon when activities and materials cannot be duplicated [5]. ICT adds values to learning in term of reaching parts of the curriculum that other teachings methods do not, for example, students of senior high school are able to study by comparing and contrasting the model of protein and nucleic acid by using $2 \mathrm{D}$ and 3D representation using animation [7]. Further, learning biology incorporating by ICT can influence and sustain students' attainment. ICT based-learning environment can help students to understand and interpret data and provide them to focus on developing conceptual understanding [8]. That effects are described by four main effects; 1) promoting students' cognitive development, 2) increasing students self- management and tracking their own learning, 3) enabling students to broaden the learning experience and relate it to realworld experience, 4) facilitating data collection and data presentation.

Creating learning with an online-based environment is also needed in the era of distance learning during pandemic. One of the forms to establish an online-based learning environment is the Learning Management System (LMS). Learning management system (LMS) is a software application or web-based technology used to plan, implement and assess a specific learning process [9]. LMS provide teacher to create and deliver learning content, monitor students' participation, and assess students' performance. It also provides interactive features such as discussion forum and video conferencing. LMS helps teacher to monitor students learning progress and performance and also update learning modules and activities easily. In addition, it also gives benefit to students that they can personalize their learning experience. Some popular LMS used by Indonesian educational institutions are Moodle and Blackboard. Research stated that learning biology on the topic of human movement systems with Moodle become more fun [10]. Another research also added that using of e-learning facilities by students in the course of Human Anatomy Physiology, increased activity of learning, and students' attitude towards human physiology and anatomy course [11].

The conversion of face-to-face learning into online learning is a challenge for biology teachers. Teachers must adapt to changing conditions to use technology in learning in a fairly short period of time. However, the use of this technology is also an opportunity for teachers to develop skills in using technology in learning, especially after the pandemic. Therefore, this study aims to explore the roles of technology in biology teaching during and post covid. The specific research question addressed during the study were: 1) what learning strategies were implemented in teaching Biology during Covid-19 pandemic, 2) what types of learning media used in teaching Biology online, 3) what is the experience of a biology teacher teaching during a pandemic, and 4) how is the readiness of biology teachers to teach after the pandemic.

\section{METHODS}

This research is a qualitative study using semi structured interview method. The participants were six biology teachers ( 4 female and 2 male) in public and private senior high schools who have more than five years of experience in teaching biology. Data was obtained by interview using open-ended question and also gathering information through Learning Management System (LMS) used in biology courses. We also investigated learning process through videos recorded by teachers during online learning. The obtained data were prepared and organized for analysis process and coded to develop a more general picture of the data. Findings were represented through narratives to interpret the meaning of the results and ultimately conducted strategies to validate the accuracy of the findings [12]. 


\section{FINDINGS AND DISCUSSION}

\subsection{Learning Strategies Used During Online Learning}

The interviews with biology teachers indicate that teaching biology has been carried out in two forms; synchronous and asynchronous. During synchronous teaching, teachers used video conferencing platforms to carry out face-to-face learning virtually with students. Teacher also explained that during asynchronous teaching, students learn biology by watching recorded lectures, watching laboratory work videos, reading materials, and doing assignments. That synchronous courses provide online learning environments that are very interactive and use web conferencing products, while in asynchronous courses provide learners with a flexible environment that is self-paced with learners accessing course content using a variety of tools such as CD-ROMs, streamed pre- recorded audio or video web recordings, and audio podcasts [13].

In synchronous teaching, the popular platforms that have been used are Google Meet and Zoom. Teachers said that the two video conferencing platforms were easy to operate. Google meet, for example, to hold a virtual class, they only need to utilize the features in their Google emails account. The virtual class link on Google Meet can also be used multiple times and can also be scheduled in advance. Another feature of Google Meet that supports learning is the video recording feature, so that students can access the learning video recording anytime. In addition, there are also chat and raise hands feature that help create interaction, for example by asking or answering questions, during the learning process. Another video conferencing platform that is popular among teachers is Zoom. Unlike Google Meet, Zoom has a feature called breakout room. This break-out room feature can facilitate teachers to create groups in synchronous session to conduct group discussions during learning.

In asynchronous learning, teachers explained that they use several platforms to support online learning during pandemic, such as Google Classroom, Microsoft Team, and LMS developed by each school. These platforms facilitate them to manage their course. They can upload the pre-recorded learning videos, learning materials in various formats (doc, pdf, or ppt), assignments, and exams. However, during asynchronous learning, they also explained that they could not rely only on these platforms. They still used massaging application such as WhatsApps in order to organize students during the learning process. It helps them in organizing students to join the virtual meeting according to the schedules or remind students to collect the assignments.

Teacher A explained that she prefers to use Google Classroom to other platforms because of its practicality. There are at least five contents shared in Google Classroom; 1) lectures notes, 2) quizzes, 3) learning resources, 4) announcement of the forthcoming events, and 5) assignment requiring submission in Google
Classroom platform [14]. By taking advantage of these features, she uploaded learning material in various forms, such as word, pdf, or ppt. She also posted the assignments there. Midterm and final exams were also conducted through Google Classroom by developing test using Google Form. Therefore, all these features can be managed in one Google Classroom, because it supported all the features.

Unlike teacher $\mathrm{A}$, Teacher $\mathrm{P}$ tend to like using Microsoft Team rather than other platforms. He mentioned that this platform makes him easily organize students' collaboration during online learning. There are three ways to support students' collaboration using Microsoft Team; 1) structuring students' discourse, 2) setting up literature- based discussions, 3) prompting communication, and 4) sharing the workload [15].

Teachers are also encouraged to use LMS which is developed by their school. In that LMS, teacher was able to manage the learning process through that website, synchronously or asynchronously. In synchronous session, the video conference can be put in on the LMS page. During asynchronous session, teachers can upload biology material to the LMS in various formats such as doc, ppt or pdf, learning media such as images, videos, animations or pre-recorded learning videos at the LMS. Teachers can also upload assignments and students submit assignments on the LMS. Moreover, exams and quizzes can also be conducted through the LMS. It is also equipped with a discussion forum feature that can be used during group discussion.

Based on the interview, teacher explained that in the beginning of pandemic, they felt unfamiliar with the LMS

"I found it difficult at first, since LMS is quite new for us. Actually, our school provide the workshop for us to learn how to use our LMS in the beginning of pandemic for three months, once a week every Friday"

In order to facilitate teacher learning how to operate and manage the LMS, their school provide workshops to train them using LMS. That workshops were organized by each school. In that workshop, teachers were trained and accustomed to using LMS.

When teachers were asked about the implementation of the laboratory work at school, they answered that carrying out laboratory work during the pandemic was a challenge for them. One of the teachers said that his class was still doing laboratory work, but only chose activity that were still possible for students to carry out experiments at home by using tools and materials they could easily find. This is how they compensate for the lack laboratory work during pandemic. Here is the example of independent laboratory work by Teacher $\mathrm{M}$. The topic was in the catalase enzyme experiment. The purpose of this laboratory work was to determine the effect of temperature and $\mathrm{pH}$ on the catalase enzyme in chicken liver. In this topic, she assigned students to investigate the effect of temperature and $\mathrm{pH}$ on the catalase enzyme in chicken liver. Before the experiment started, she would give directions about the objectives 
and background of the experiments, tools and materials, procedures through Google Meet. Usually, she would also provide students with a laboratory work manual so that students could study individually before the virtual meeting.

Another method to replace the laboratory work is using pre-recorded demonstrations to show experimental activities to students. Moreover, teachers also use videos from other sources such as YouTube to show the correct and ideal laboratory work process. However, they would not let students watch the video without their guidance. They still accompany students in order to give further explanation about the procedures in the videos.

In carrying out exams; whether mid-term, final exams, or quizzes; teachers explained that they had carried out the online exams using Google Forms. The implementation of the exam using Google Forms makes it easier for them to compose questions in various forms, from multiple choice, matching, to essays. Google Forms also make it easier for them to check and grade the exams, because they can make a rubric or answers which will then grade students' exams automatically. Teachers also utilized game-based learning in their class. They used Kahoot! and Quizizz in order to carry out quizzes.

Using gamification in biology teaching can increase students' motivation and achievement [22]. It has positive influence to students learning process through error during playing games. It is also important to students' emotional and social aspects. Kahoot as one of an example of game-based learning platforms can be used as assessment tool to help students learning biology. These activities had positive impact to both teacher and students as the students enjoyed learning biology [23].

\subsection{Types of Learning Media Used During Online Learning}

Based on the results of interviews, teachers use various forms of learning media during online learning. Teachers use media from pictures, videos, animations to virtual laboratories. When asked whether they had used augmented reality or virtual reality, only one teacher had already used it. Teacher R said, "My school actually has started introducing the use of augmented reality to students before this pandemic started. So, our school has a biology book that facilitates the use of augmented reality." The use of various forms of media is teachers' efforts to presents biological objects in the classroom as students cannot see and observe directly in online learning due to the pandemic.

Using technology-based media in biology classroom influence students' motivation in learning. There was a difference of students' achievement between the academic performance of students in Biology who were exposed to computer technology and those exposed to the traditional method of teaching [6]. The use of multimedia to enhance understanding of abstract concepts can be supported with the use of both formal science language and informal talk by teachers and students [7]. It is therefore recommended that integrating computer technology into Biology teaching can enhance students' academic performance.

\subsection{Teacher Experiences Using Technology in Biology Teaching}

Teacher experience using technology are divided int two parts, the obstacles faced by teacher and the benefits in using technology during online learning. When teachers were asked about the difficulties in teaching during the pandemic, they mentioned several things related to their interactions with students. In virtual class session, teachers sometimes find it difficult to interact with students. Sometimes, they were not as engaged as compared to face-to-face learning. There is best practice to promote students' engagement in online class including 1) offering challenge and connecting content with how it can be applied and useful, (b) collaborative and active approaches to learning should be used, (c) there should be quality interactions between the students and between the instructor and students, and (d) courses should include enriching experiences [16]. In order to increase the engagement of students, teacher should develop online etiquette, such as turning on the cameras, unmuting microphones, using rise hand tools, chat box, and asking or answering question during synchronous session [17].

The teachers said that sometimes it was difficult to raise students' enthusiasm in learning. It was difficult to invite them to attend class on time. This was because students had issues relating to the supported technology used such as internet access, phone connection, or computers being shared. In addition, students must also be reminded to return to class the previous day. Teachers also added that it was the same when doing the assignments. They must announce the assignment in advance through the WhatsApp application, because students rarely open the learning platform if they are not asked to do so. Therefore, it is important to develop rules regarding to monitor students' participation during online learning.

Teachers also encounter difficulties when students have to collaborate. This happened because they did not meet face-to-face. However, teachers do try to maximize the use of technology to facilitate discussion and collaboration activities. One of the teachers said that they used several platforms from Google Jam board, Microsoft Team, and Google Slides to breakout room in Zoom in order to make the collaboration process happen a breakout room. Teachers also said their experience 
using Google Jam Board that ir can increase students' participation during discussion in his class. Unlike teacher $\mathrm{P}$, teacher $\mathrm{R}$ prefer to use breakout room in Zoom because of its practicality. Thus, using computer technology into the biology learning motivate students to be active participants during learning process [6].

\subsection{Teachers Readiness in Dealing with Biology Teaching at Post-Covid Era}

According to the interview, teachers said that in post-pandemic learning, teaching biology will still use technology. Based on their experience, learning nowadays cannot be separated from the use of technology, because technology makes it easier for them to design learning instruction and conducting teaching process, especially with the characteristics of the students, alpha generation, who they are currently teaching.

Skills in using this technology are part of the pedagogical technology, and content knowledge (TPACK) that must be possessed by teachers. TPACK is a framework developed on the interaction of knowledge of technology, pedagogy, and content to produce effective learning by integrating technology. The framework is composed by seven aspects; 1) technological knowledge, 2) pedagogical knowledge, 3) content knowledge, 4) knowledge of technology content, 5) pedagogical content knowledge, 6) pedagogical knowledge of technology, 7) pedagogical technology knowledge of content [18]. Therefore, to create a successful and sustainable ICT-based learning environment, these teachers need to have this framework.

Based on the interview, teachers are prepared for teaching in the new-normal. Even though they feel they are ready to face new normal, they still do prepare a lot of things. At least, there are three big changes that education should make post COVID; curriculum, pedagogy, and organization. A curriculum should help students develop the new competencies for the new age, focus more on developing students' capabilities, concern with students' social and emotional wellbeing, experience global education that globally and environmentally connected. The curriculum also should allow personalization by students that student can develop their unique learning pathways. It gives students the opportunity to choose learning content and further find their passion and strength. It benefits students in the long term because it makes them become the owner of their learning and develop life-long learning habits and skills. Pedagogy should change as well. Learning should be student- centered, inquiry based, authentic, and purposeful. It also emphasizes on the development of student's ability such as problem solving. Teacher also should encourage students to be more actively engaged in their own learning and know their learning pathway. Moreover, school as an educational institution should adjust as well as the curriculum and pedagogy. Technology has made it possible for school to offer online education during this pandemic time. It also gives opportunities to teacher to rethink the purposes of teaching and connecting to students. Teaching nowadays is not only about delivering the material from a teacher to students in the certain time and place, but also learning from teachers or experts anywhere in the world and learning form online resources. Furthermore, asynchronous teaching made it possible for students to learn at any time. It makes their learning time also expands beyond traditional school time. This type of learning also encourages students to make connection globally [19].

A well-balanced combination between synchronous and asynchronous is a new and more effective models to be practiced during distanced learning. This combination gives opportunity to conduct inquiry-based learning especially in learning science such as biology course. Students will get instruction in synchronous meeting or pre-recorded lectures from teacher before conducting inquiry. This inquiry process can be implemented individually or within small group. Students are also allowed to manage small group meeting synchronously to discuss as a part of inquiry process. The results from those activities can be discussed and presented in large class synchronous meeting [19].

Teachers seem to be very enthusiastic in using technology in teaching biology. Teachers' enthusiasm, confidence and skills for using ICT are significant motivational factor affecting the successful teaching practice [20]. This high motivation is also influenced by their strong beliefs and their preference for implementing particular teaching approach. Additionally, teachers will be more prepared in teaching online courses [17]. However, teachers are still need to be more prepared and have much to learn in facing the new-normal [21].

Taking into account, teachers still need training programs to increase their ICT skills and pedagogical knowledge particularly in online learning instruction design. It is necessary because it can enhance their productivities and their flexibility to adapt to the development of learning instructions, so that they can adjust to the different learning settings (online leaning, blended-learning, or flipped learning). Moreover, it is also important to build connection among biology teachers so that they get the opportunities to exchange experiences with others. 


\section{CONCLUSIONS}

The Covid-19 pandemic caused major changes in the education system. Teachers and curriculum were forced to adjust the implementation of learning process. We have to change traditional face-to-face learning to online learning. This change provides an opportunity for teachers, especially biology teacher, to adapt implementing technology in biology learning. Teachers also use various learning media such as: photos, videos, animations, augmented reality, and virtual laboratories, especially to help them conducting laboratory work. During the online learning process, teachers experience many obstacles such as technical issues, reduced interaction between teachers to students and between students. Despite these obstacles there is optimism that these obstacles can be overcome through integrating technology in learning. The Online learning will continue in the future, with various forms such as learning that combines online learning and face-to-face learning such as blended learning or flipped learning.

\section{REFERENCES}

[1] B. B. Lockee, Online Education In The PostCOVID Era. Nat Electron, 2021, Vol. 4, 5-6.

[2] D. Conrand, J. Openo, Assesment Strategies for Online Learning. AU Press, Edmonton, 2018.

[3] N. D. Vaughan, M, Cleveland-Innes, D. R. Garrison, Assessment in Teaching in Blended Learning Environments: Creating and Sustaining Communities of Inquiry. Athabasca Univ Press, Athabasca, 2013.

[4] C. Crindland, T, Drape, S. Marine, G. Gillaspy. Ten Best Practice for Taking Experiental Learning Online. Biochem Mol Biol Educ, 2020, 1-6.

[5] C. Lemon, using technology to teach content in a student teaching experience (and as a first-year teacher), Contemporary Issues in Technology and Teacher Education, Vol. 5(1), 2005.

[6] Y. Garraway-Lashley, Integrating Computer Technology I the Teaching Biology. International Journal of Biology Education, Vol. 32014.

[7] J. Wellington, Has ICT come of age? Recurring debates on the role of ICT in education, 19822004 Research in Science and Technology Education, Vol. 23: 25-39, 2005.

[8] M. E. Webb, Affordances of ICT in science learning: Implications for an integrated pedagogy. International Journal of Science Education, Vol. 27, 2005, pp. 705-35.

[9] K. Brush, Learning Management System. Retrieved from https://searchcio.techtarget.com/ definition/learning-management-system, 2019.

[10] I, Murdiani, Pembelajaran biologi menggunakan metode e-learning berbasis multiple intelligences pada materi sistem gerak manusia. Innovative Journal of Curriculum and Educational Technology, Vol. 1 (1), 2012.

[11] A. A. Azis, Pengembangan Media E-Learning Berbasis Lms Moodle Pada Matakuliah Anatomi Fisiologi Manusia. Jurnal Pendidikan Biologi, Vol. 7 (1), 1-8, 2015.

[12] J. W. Creswell, Educational Research $4^{\text {th }}$ Edition. Pearson, Boston (MA), 2012.

[13] A. A. Skylar, A Comparison of Asynchronous Online Text-Based Lectures and Synchronous Interactive Web Conferencing Lectures. Issues in Teacher Education, Vol. 18 (2), 2009, pp. 69-84.

[14] S. Dash, Google Classroom as A Learning Management System to Teach Biochemistry In A Medical School. Biochem Mol Biol Educ, 2019, Vol 47. pp. 404-407.

[15] K. Hellenrich, Using Microsoft Teams in a Hybrid Classroom. Retrieve: https://www.edutopia.org/ article/using-microsoft-teams-hybrid-classroom 2020.

[16] A. Khan, O. Egbue, B. Palkie, J. Madden, Activelearning: Engaging students to maximize learning in an online course. EJEL, Vol. 15(2), 2017, pp. 107-115.

[17] L. S. Neuwrith, S. Jovic, B. R. Mukherji, Reimagining higher education during and postCOVID-19: Challenges and opportunities. Journal of Adult and Continuing Education, Vol. 0(0), 2020, pp. 1-16.

[18] M. J. Koehler, P. Mishra, What happens when teachers design educational technology? The development of Technological Pedagogical Content Knowledge. Journal of Educational Computing Research, Vol. 32, 2005, pp. 131-152.

[19] Y. Zhao, J. Watterson, sthe changes we need: Education post COVID-19. Journal of Educational Change, Vol. 22, 2021, pp. 3-12.

[20] R. Daeney, S. Hennessy. Sustainability, Evolution and Dissemination Of Information And Communication Technology-Supported Classroom Practice. Research Papers in Education, Vol. 22 (1), 2007, pp. 65-94.

[21] J.L. Wilson, A. Hensley, A. Culp-Roche, D. Hampton, F. Hardin-Fanning, A. ThaxtonWiggins, Transitioning to Teaching Online During the COVID-19 Pandemic. Sage Open Nursing, Vol, 7, 2021, pp 1-9.

[22] I. U. Yapici. F. Karakoyun, Gamification in Biology Teaching: A Sample of Kahoot Application. Turkish Online Journal of Qualitative Inquiry, Vol. 8(4), 2017, pp. 396-414.

[23] S. M. Jones, et al, A 'KAHOOT' Approach: The Effectiveness of Game-based Learning for an Advanced Placement Biology Class. Simulation \& Gaming, Vol. 0(0), 2019, pp. 1-6. 